\title{
RAPID DIAGNOSIS OF RUBELLA BY DEMONSTRATING RUBELLA-SPECIFIC IgM ANTIBODIES IN THE SERUM BY INDIRECT IMMUNOFLUORESCENCE
}

\author{
Margaret Haire and Diana S. M. Hadden \\ Department of Microbiology, The Queen's University of Belfast
}

RECENT rubella can be diagnosed by finding rubella haemagglutination-inhibiting (HI) antibodies in the immunoglobulin $\mathrm{M}(\mathrm{IgM})$ fraction of serum after its separation by sucrose density ultracentrifugation (Vesikari and Vaheri, 1968; Best, Banatvala and Watson, 1969; Desmyter, South and Rawls, 1971), or by detecting rubella-specific IgM antibody in the serum by indirect immunofluorescence (Baublis and Brown, 1968; Cohen et al., 1968). By these means diagnosis of recent infection can be made from a single serum specimen from the patient at a time when the HI antibody is already elevated and a diagnostic rise can no longer be shown. We are reporting the evaluation of the indirect immunofluorescent technique, confirmation of its use in diagnosis and comparison of its sensitivity with direct immunofluorescent staining of virus antigen in infected cells from the throat and with virus isolation.

\section{MATERIALS AND METHODS}

\section{Patients}

Serial specimens of serum were obtained from 21 patients with clinical rubella during an epidemic. In eight of these patients, three sera were taken during the $1 \mathrm{st}$ wk, further specimens at the end of the 2nd, 3rd and 7th wk approximately, and a final serum between 3 and 6 mth after the appearance of the rash. Sera were collected from the 13 other patients at various times after onset. Sera were stored at $-20^{\circ} \mathrm{C}$ and all the samples from each patient were examined at the same time in the different antibody tests. Throat swabs were taken from all patients at the first visit, for diagnosis by both direct immunofluorescence and virus isolation.

\section{Detection of rubella-specific IgM and IgG antibodies in serum}

(1) Antigen. BHK21 cells growing on coverslips were infected with the Judith strain of rubella virus. After $72 \mathrm{hr}$ they were fixed in fresh acetone for $10 \mathrm{~min}$. at room temperature, air-dried for $30 \mathrm{~min}$. and stored at $-20^{\circ} \mathrm{C}$ in the presence of silica gel.

(2) Fluorescein conjugates. Sheep anti-human IgM and sheep anti-human IgG (Wellcome Reagents, Ltd) conjugated with fluorescein isothiocyanate (FITC) (Sigma Chemical Company) were used to titrate rubella-specific IgM and IgG antibodies in the serum specimens from the first eight patients. Subsequently, a batch of anti-human IgM conjugated with FITC (Wellcome Reagents, Ltd), which had been tested and evaluated for specificity (Chantler and Haire, in press), was employed for the detection of rubella-specific IgM in the diagnostic tests for recent rubella infections.

(3) Adsorption of sera and conjugates. All conjugates were adsorbed with BHK21 cells. Sera were adsorbed with mouse-liver powder. Some serum samples were adsorbed in parallel

Received 8 Sept. 1971; accepted 27 Sept. 1971.

J. MED. MICROBIOL.-VOL. 5 (1972) 
with mouse-liver powder or BHK21 cells and the results of antibody estimations on sera adsorbed in both ways were compared. Adsorption was carried out overnight at $4^{\circ} \mathrm{C}$.

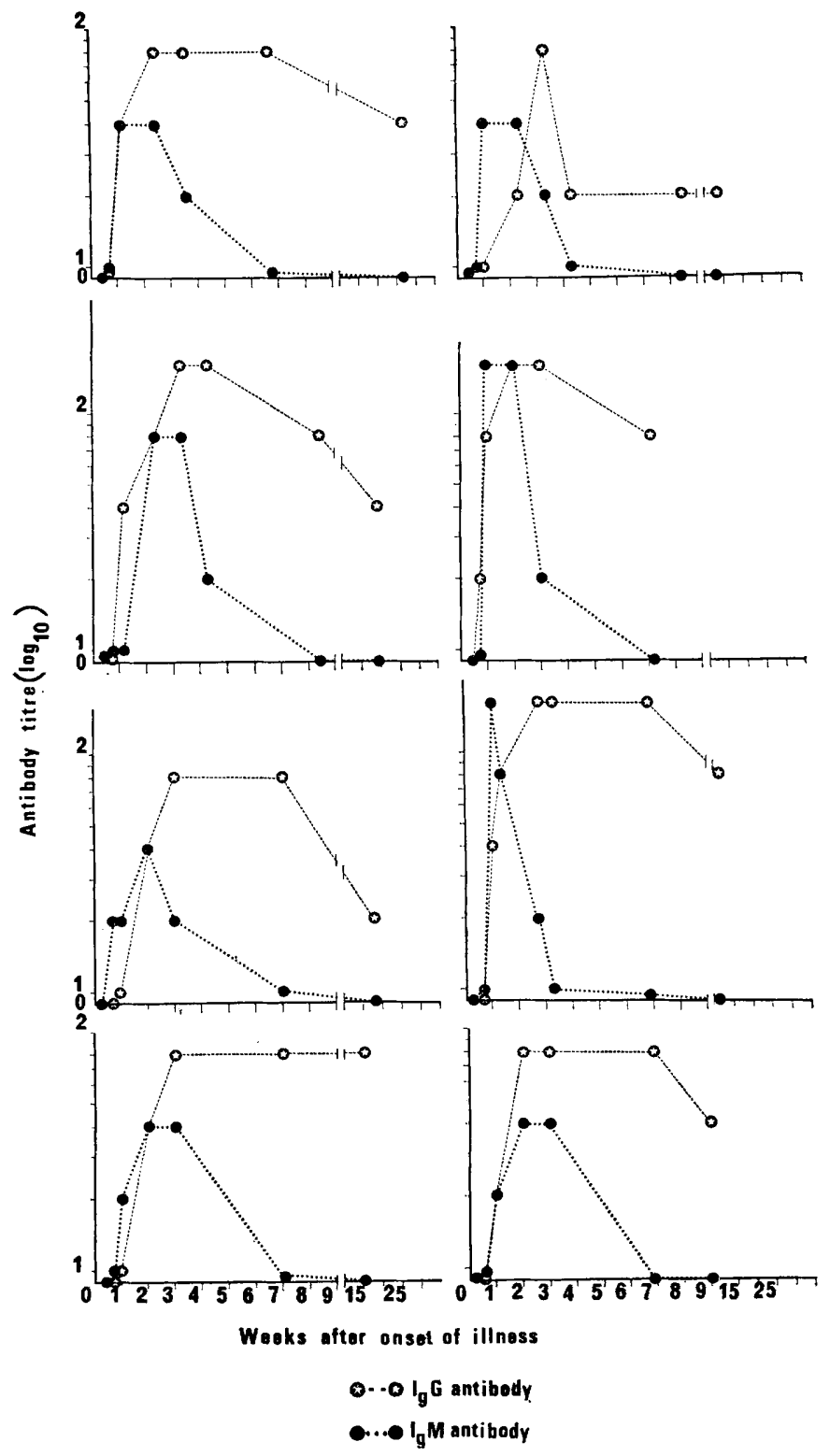

FIGURE.--Rubella-specific IgM and IgG antibody responses in eight patients with rubella.

(4) Staining. Dilutions of patient's adsorbed sera were applied to coverslip preparations of rubella-infected cells for $1 \mathrm{hr}$ at room temperature. The coverslips were then thoroughly washed and conjugate was applied for $1 \mathrm{hr}$ at $35^{\circ} \mathrm{C}$. After a final wash, each coverslip was dipped in 1 in 150,000 Evans blue and mounted in glycerol-saline, $p \mathrm{H} \mathrm{8 \cdot 3.}$

(5) Control viruses. Patients' sera were tested at a dilution of 1 in 5 for specific IgM antibodies to mumps and measles viruses by the same techniques as described above. 


\section{Diagnosis by virus isolation, direct immunofluorescence of cells in} throat swabs and serum HI antibody tests

The techniques used are described in the accompanying paper (Haire and Hadden, 1972).

\section{RESULTS}

Eight patients were used for an initial study of the IgM and IgG antibody responses in acute rubella; seven of them were aged 17 to $29 \mathrm{yr}$, and one of them was $38 \mathrm{yr}$ old. All of them were confirmed as cases of acute rubella by virus isolation and by demonstrating a significant rise of $\mathrm{HI}$ antibody during the course of illness. The figure shows the post-infection levels of rubella-specific IgM and IgG antibodies, as estimated by indirect immunofluorescence, in the eight patients. In all the patients IgM antibodies appeared within 5 days of onset of the rash; the IgG antibodies appeared slightly later and were not detected in all patients until the 7th day. Both antibodies reached peak titres within $2 \mathrm{wk}$. This stresses the need to collect the acute specimen of serum, for routine HI tests, as soon as possible after onset of illness to be able to demonstrate a rising titre of antibody. The IgG antibodies remained at a high level but the IgM antibodies fell rapidly and became undetectable (in serum dilutions of 1 in 5) in most of the patients after $7 \mathrm{wk}$ and in all eight patients after $9 \mathrm{wk}$. These findings confirm that the presence of $\operatorname{IgM}$ antibodies in a single serum specimen from a patient is diagnostic of current or recent rubella.

In control tests with mumps and measles viruses, neither mumps-specific nor measles-specific IgM antibodies were found in the sera of the eight patients. Similar titres of rubella antibodies were obtained for the various serum specimens whether they were absorbed with BHK21 cells or with mouse-liver powder.

The reliability of the indirect immunofluorescence test for the routine diagnosis of rubella was now examined in 13 other patients. Three serial serum specimens were collected from each patient, the first in the 2nd wk of illness, the second in the 3rd wk and the third at some time later than $6 \mathrm{wk}$ after the appearance of the rash. The 39 sera were coded and were tested simultaneously, at a dilution of 1 in 5, together with several known positive and negative control sera, also coded, for rubella-specific IgM antibody. The results of these tests and of other diagnostic tests carried out on the 13 patients are shown in the table. Every serum specimen collected between the 6th day and the 23rd day after onset of illness contained rubella-specific IgM antibody, but this was absent from specimens obtained later than the 44th day.

The indirect immunofluorescence test for rubella-specific IgM (positive in all 21 cases examined) proved to be more sensitive for diagnosis than either virus isolation (positive in only 15 cases) or direct immunofluorescence of infected cells in throat swabs (positive in 14 cases).

\section{Discussion}

The laboratory is often requested to provide rapid confirmation, or otherwise, of rubella in pregnancy. In many instances the patient is first seen a week, 
TABLE

Appearance of rubella haemagglutination-inhibiting (HI) antibodies and rubella-specific IgM antibodies in 13 patients with clinical rubella

\begin{tabular}{|c|c|c|c|c|c|}
\hline \multirow{2}{*}{$\begin{array}{l}\text { Sex and } \\
\text { age of } \\
\text { patients }\end{array}$} & \multicolumn{2}{|c|}{$\begin{array}{l}\text { Haemagglutination- } \\
\text { inhibiting antibodies }\end{array}$} & \multicolumn{2}{|c|}{$\begin{array}{l}\text { Rubella-specific } \\
\text { IgM antibodies }\end{array}$} & \multirow{2}{*}{$\begin{array}{l}\text { Diagnosis by virus } \\
\text { isolation (VI) and } \\
\text { direct immuno- } \\
\text { fluorescence of } \\
\text { cells in throat } \\
\text { swabs (IF) }\end{array}$} \\
\hline & $\begin{array}{l}\text { Days after } \\
\text { onset of } \\
\text { illness }\end{array}$ & $\begin{array}{c}\text { Titre } \\
\text { of } \\
\text { antibody }\end{array}$ & $\begin{array}{l}\text { Days after } \\
\text { onset of } \\
\text { illness }\end{array}$ & $\begin{array}{l}\text { Present } \\
\text { at } \frac{1}{5} \\
\text { dilution } \\
\text { of serum }\end{array}$ & \\
\hline F. 13 & $\begin{array}{l}1 \\
9\end{array}$ & $\begin{array}{r}32 \\
256\end{array}$ & $\begin{array}{r}9 \\
22 \\
61\end{array}$ & 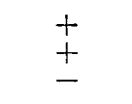 & $\mathrm{VI}+\mathrm{IF}-$ \\
\hline M. 6 & $\begin{array}{r}3 \\
10\end{array}$ & $\begin{array}{r}32 \\
512\end{array}$ & $\begin{array}{l}10 \\
23 \\
60\end{array}$ & $\begin{array}{l}+ \\
+ \\
-\end{array}$ & $\mathrm{VI}-\quad \mathrm{IF}+$ \\
\hline F. 7 & $\begin{array}{l}2 \\
9\end{array}$ & $\begin{array}{r}8 \\
128\end{array}$ & $\begin{array}{r}9 \\
16 \\
63\end{array}$ & $\begin{array}{l}+ \\
+ \\
+\end{array}$ & $\mathrm{VI}+\mathrm{IF}-$ \\
\hline M. 6 & $\begin{array}{r}3 \\
10\end{array}$ & $\begin{array}{r}32 \\
256\end{array}$ & $\begin{array}{l}10 \\
17 \\
63\end{array}$ & $\begin{array}{l}+ \\
\pm \\
+\end{array}$ & VI $+\quad$ IF + \\
\hline M. 8 & $\begin{array}{r}4 \\
19\end{array}$ & $\begin{array}{r}8 \\
64\end{array}$ & $\begin{array}{l}12 \\
19 \\
67\end{array}$ & \pm & VI- $\mathbf{I F}+$ \\
\hline M. 13 & $\begin{array}{r}4 \\
14\end{array}$ & $\begin{array}{r}32 \\
1024\end{array}$ & $\begin{array}{l}14 \\
22 \\
58\end{array}$ & $\begin{array}{l}+ \\
+ \\
+\end{array}$ & VI- IF+ \\
\hline F. 10 & $\begin{array}{r}2 \\
16\end{array}$ & $\begin{array}{r}16 \\
128\end{array}$ & $\begin{array}{l}10 \\
23 \\
54\end{array}$ & $\begin{array}{l}+ \\
+ \\
-\end{array}$ & VI- IF + \\
\hline M. 8 & $\begin{array}{r}3 \\
10\end{array}$ & $\begin{array}{r}8 \\
256\end{array}$ & $\begin{array}{l}10 \\
17 \\
52\end{array}$ & $\begin{array}{l}+ \\
+ \\
-\end{array}$ & $\mathrm{VI}+\mathrm{IF}-$ \\
\hline F. 8 & $\begin{array}{r}3 \\
10\end{array}$ & $\begin{array}{r}32 \\
256\end{array}$ & $\begin{array}{l}10 \\
23 \\
44\end{array}$ & $\begin{array}{l}+ \\
+ \\
+\end{array}$ & $\mathrm{VI}-\mathrm{IF}+$ \\
\hline F. 18 & $\begin{array}{l}3 \\
7\end{array}$ & $\begin{array}{r}8 \\
512\end{array}$ & $\begin{array}{l}7 \\
23 \\
23 \mathrm{wk}\end{array}$ & $\begin{array}{l}+ \\
+ \\
-\end{array}$ & $\mathrm{VI}+\mathrm{IF}+$ \\
\hline F. 16 & $\begin{array}{l}3 \\
8\end{array}$ & $\begin{array}{r}64 \\
2048\end{array}$ & $\begin{array}{l}6 \\
22 \\
18 \text { wk }\end{array}$ & $\begin{array}{l}+ \\
\pm\end{array}$ & $\mathrm{VI}+\quad \mathrm{IF}-$ \\
\hline M. 16 & $\begin{array}{l}2 \\
7\end{array}$ & $\begin{array}{r}32 \\
1024\end{array}$ & $\begin{array}{l}7 \\
16 \\
17 \mathrm{wk}\end{array}$ & $\begin{array}{l}+ \\
+\end{array}$ & $\mathrm{VI}-\mathrm{IF}+$ \\
\hline F. 39 & $\begin{array}{l}5 \\
8\end{array}$ & $\begin{array}{r}32 \\
256\end{array}$ & $\begin{array}{l}8 \\
18 \\
20 \text { wk }\end{array}$ & $\begin{array}{l}+ \\
+ \\
-\end{array}$ & $\mathrm{VI}+\mathrm{IF}+$ \\
\hline
\end{tabular}


or even later, after the appearance of the rash, by which time it may no longer be possible to demonstrate a rising titre of $\mathrm{HI}$ antibodies.

Banatvala et al. (1970) and Desmyter et al. (1971) have described an alternative method for demonstrating rubella-specific $\operatorname{IgM}$ antibody in serum; the IgM component of the serum is separated by sucrose-density ultracentrifugation and the rubella-specific antibody in it is demonstrated by an HI test. The latter workers found IgM antibody to rubella to persist for no longer than $1 \mathrm{mth}$ after onset of illness in 17 women with proven rubella in the first trimester of pregnancy. Our experience with the indirect immunofluorescent technique for demonstrating the presence of rubella-specific IgM confirms that recent rubella can be diagnosed from a single specimen of serum collected between 6 days and 23 days after the appearance of the rash in 100 per cent. of patients. In some cases the IgM antibody may persist for a further $2 \mathrm{wk}$.

A direct comparison of the two methods of detecting rubella-specific IgM would be valuable. However, we feel that our method is the simpler, especially as it is now possible to obtain commercially reliable preparations of anti-human IgM fluorescein-conjugate.

In our studies of 21 patients the indirect immunofluorescence test for rubellaspecific IgM antibody in serum proved to be more sensitive for diagnosis than the demonstration of virus antigen in infected cells in throat swabs by direct immunofluorescence. On the other hand, most serum specimens for the indirect test were collected during the 2 nd and 3 rd wk after onset of illness, when this test is obviously more valuable, while throat swabs for the direct immunofluorescent test were obtained during the 1st wk of illness. The latter test may be especially useful during this early period when IgM antibody may not yet have appeared. Further comparative studies of these two tests are needed. However, the indirect immunofluorescence test is quicker technically to carry out than the direct test, as the harvesting of the cells from the throat swab and their preparation on slides takes some considerable time. We would therefore recommend it as the method of choice when there is urgency concerning an accurate diagnosis of recent rubella infection.

\section{SUMMARY}

The normal responses of rubella-specific IgM and $\operatorname{IgG}$ antibodies were studied in eight patients with proven rubella by the indirect immunofluorescent technique. To evaluate the detection of rubella-specific IgM for diagnosis, a " blind" study of sera from 13 other patients with proven rubella was carried out and the method proved to be 100 per cent. reliable. Its sensitivity was compared with virus isolation and with direct immunofluorescent staining of virus antigen in infected cells from throat swabs.

We wish to thank the patients and their doctors for their co-operation. Dr Florence Curran helped in obtaining specimens, and the Misses Anne J. Fulton and Elizabeth M. Henderson gave technical assistance. Professor K. B. Fraser gave valuable advice.

This work was supported by a grant from the National Fund for Research into Crippling Diseases. 


\section{REFERENCES}

Banatvala, J. E., Best, Jennifer M., Bertrand, J., Bowern, Narelle A., and Hudson, SheILA M. 1970. Serological assessment of rubella during pregnancy. Br. Med. J., 3, 247.

Baublis, J. V., AND Brown, G. C. 1968. Specific response of the immunoglobulins to rubella infection. Proc. Soc. Exp. Biol. Med., 128, 206.

Best, Jennifer M., Banatvala, J. E., AND Watson, D. 1969. Serum IgM and IgG responses in postnatally acquired rubella. Lancet, 2,65 .

Chantler, Shireen, AND HaIre, Margaret. In press. Evaluation of the immunological specificity of fluorescein-labelled anti-human IgM conjugates, Immunology.

Cohen, Sophia M., Ducharme, Claire P., Carpenter, Charlotte A., and Deibel, R. 1968. Rubella antibody in IgG and IgM immunoglobulins detected by immunofluorescence. J. Lab. Clin. Med., 72, 760.

Desmyter, J., South, Mary A., and Rawls, W. E. 1971. The IgM antibody response in rubella during pregnancy. J. Med. Microbiol., 4, 107.

Haire, Margaret, and Hadden, Diana S. M. 1972. Rapid diagnosis of rubella by direct immunofluorescent staining of desquamated cells in throat swabs. J. Med. Microbiol., $5,231$.

VeSIKARI, T., AND VAHERI, A. 1968. Rubella: a method for rapid diagnosis of a recent infection by demonstration of the IgM antibodies. Br. Med. J., 1, 221. 